\title{
Ipomoea imperati beach morning-glory \\ Ipomoea pes-caprae subsp. brasiliensis railroad vine
}

\section{Convolvulaceae}

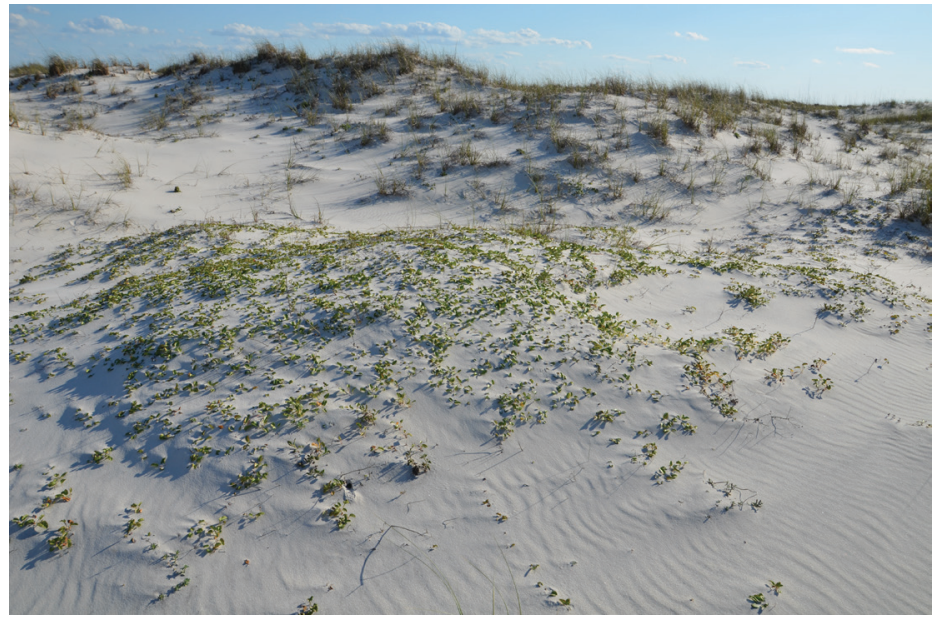

Credit: Gabriel Campbell, UF/IFAS

Two species of Ipomoea are found in coastal beach plant communities of the Florida Panhandle; beach morning-glory (Ipomoea imperati) and railroad vine (Ipomoea pes-caprae subsp. brasiliensis). Beach morning-glory and railroad vine are distinguished by the colors of their corollas and the shapes of their leaves. Beach morning-glory flowers are white with yellow and purple in the throat and leaves are elliptical and notched; whereas railroad vine has a pink to purple flower and kidney-shaped leaves. Beach morning-glory flowers occur from spring to fall, while railroad

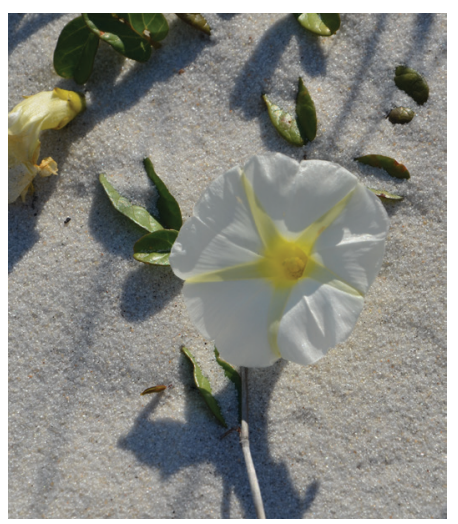

Credit: Gabriel Campbell, UF/IFAS vine flowers are present year-round.

Both plants occur throughout coastal Florida, however railroad vine has been documented in more counties. More broadly, these plants are found in coastal states west to Texas and northeast to North Carolina. Disjunct populations may exist in Pennsylvania as well.
Both species have been reported to occur there. These plants occur in beach dunes and are important sand stabilizers and colonizers after disturbances. The seeds are important forage for several types of wildlife, including endangered beach mice.

\section{General Description}

Both species are stoloniferous, scrambling, creeping perennial vines that reach extreme lengths, upward of 30 $\mathrm{ft}$ or more. Leaves are simple and alternately arranged, with or without lobes. They have elongated petioles. Stems are trailing, fleshy, and glabrous, forming roots at nodes. Inflorescences are solitary and axillary. Sepals are coriaceous, glabrous, or pubescent, and corollas are funnelform to campanulate (funnel to bell shaped) with 5 stamens and the style included in the corolla. Interestingly, railroad vine flowers only last one day. Fruits are dry, dehiscent capsules with 4 large seeds.

\section{Propagation}

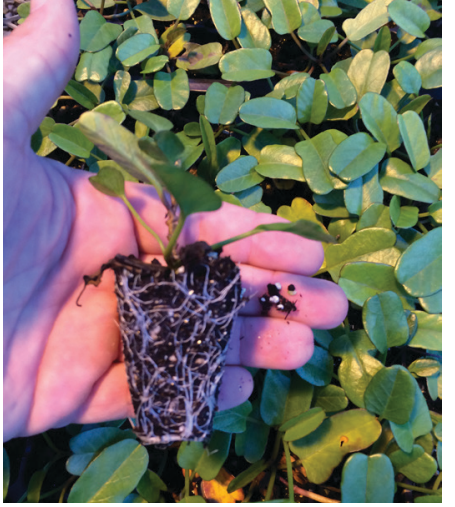

Credit: Mack Thetford, UF/IFAS
The authors propagate beach morning-glory stem cuttings without the application of auxins. Single- or multiple-node stem cuttings can be taken along any portion of the stem. Place at least one node into the rooting substrate and place under intermittent mist with natural photoperiod until roots form. Cuttings root within 7 to 10 days and should be removed from mist at the first sign of rooting, or they will quickly deteriorate. Hand water until plants form sufficient roots to hold the propagation substrate when removed from the propagation cell.

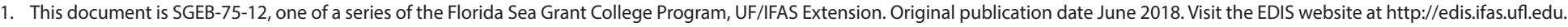

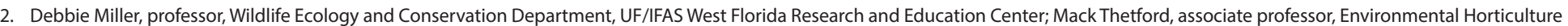

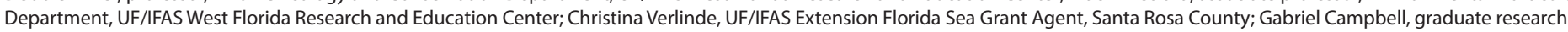

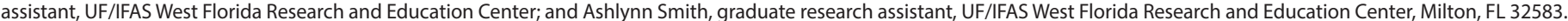




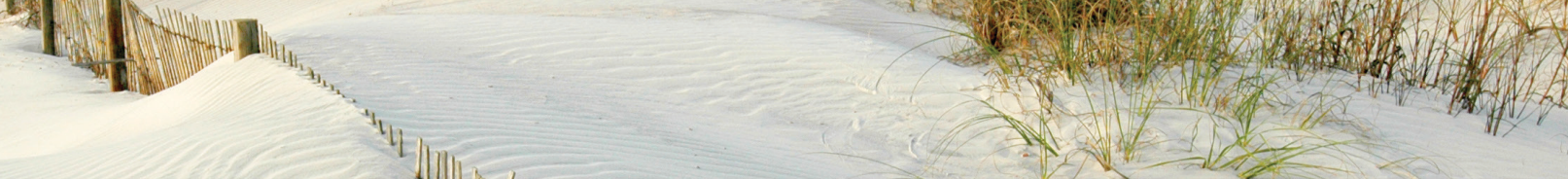

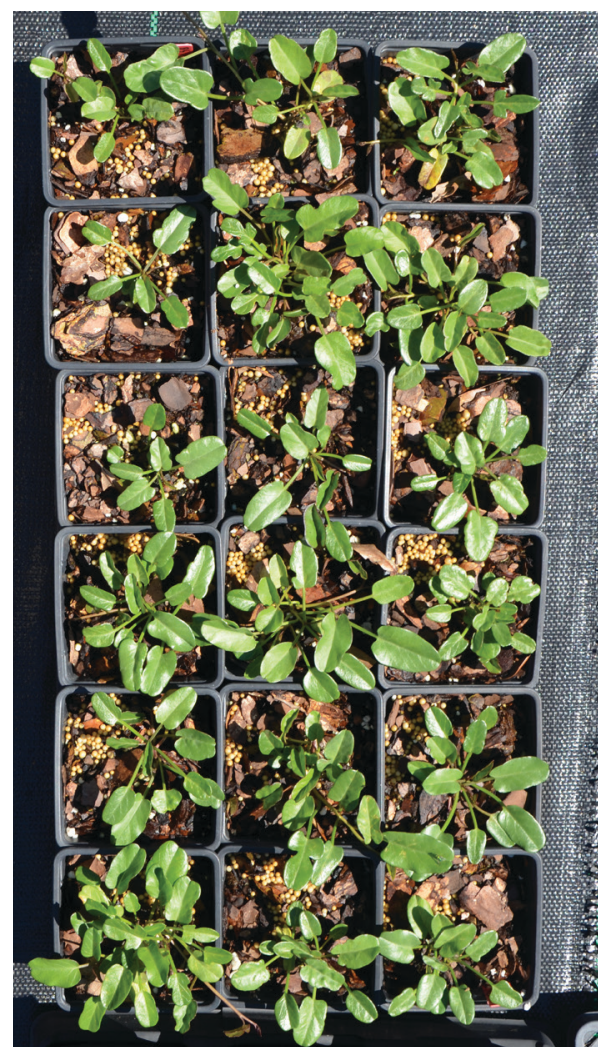

Credit: Gabriel Campbell, UF/IFAS

Plants grow quickly once transferred to production containers with a well-draining substrate in either greenhouse or nursery conditions. Railroad vine can also be propagated from cuttings in a similar manner. Seeds of railroad vine are physically dormant and must be scarified in order to germinate (Devall and Thien 1989). In the wild, seeds germinate during all seasons except for winter (Devall 1992).
Germination for beach morningglory requires scarification because seeds are physically dormant (Martínez et al. 1992). Seeds germinate with both constant ( $90 \%$ at $35^{\circ} \mathrm{C}$ ) and fluctuating day/night temperatures (60 to $85 \%$ at $40 / 20^{\circ} \mathrm{C}$ ) in dark or light. Seeds retain germinability when buried up to 0.75 in and inundated with $25 \%$ seawater.

\section{Outplanting}

No published outplanting information is available. The authors have transplanted beach morning-glory in spring and early summer months with high success. Transplants may experience an initial foliar salt burn when transferred from the nursery to high salt and wind conditions. However, transplants will quickly regrow from existing stems or from the base of the plant because of the stoloniferous characteristics of the species.

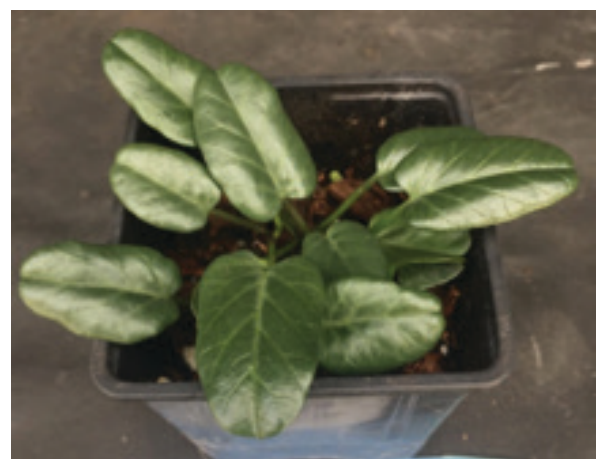

Credit: Mack Thetford, UF/IFAS

\section{Literature Cited}

Devall, M.S. 1992. “The biological flora of coastal dunes and wetlands 2. Ipomea pes-caprae (L.) Roth." Journal of Coastal Research. 8(2)442-456.

Devall, M.S., and L.B. Thien. 1989. "Factors influencing the reproductive success of Ipomoea pes-caprae (Convolvulaceae) around the Gulf of Mexico." American Journal of Botany. 76(12):1821-1831.

Martínez, M.L., T. Valverder, and P. Moreno-Casasola. 1992. "Germination response to temperature, salinity, light and depth of sowing of ten tropical dune species." Oecologia. 92:343-353. 